\title{
Producing and appropriating neighbourhood prestige: cultural capital in Australia's elite suburbs
}

\begin{abstract}
Bourdieu's theory of capital can contribute to geographies of elites and the super-rich, as a lens through which spaces of consumption, such as the residential neighbourhood, can also be understood as spaces where capital is accumulated in its varied economic, social and cultural guises. In this paper, I examine how residents of highly affluent neighbourhoods produce and sustain the prestige or distinction of their neighbourhood, and how they appropriate it as their own cultural capital. Addressing this question empirically, I analyse qualitative data from interviews with 46 residents of three of Australia's most affluent neighbourhoods: Mosman (Sydney), Toorak (Melbourne) and Cottesloe (Perth). The analysis uncovers the practices - from consumption of luxury houses and cars to 'everyday conservatism' - through which distinction becomes spatially fixed in elite neighbourhoods, and appropriated by residents, however unevenly across lines of gender, age and other social differences. I argue that distinguishing between different phases of the cultural capital circuit - the performance, appropriation and operationalisation of distinction - can help address geographers' unease with matters of agency, social difference and spatiality in Bourdieu's theory of cultural capital.
\end{abstract}

\section{Keywords}

Cultural capital; Habitus; Neighbourhood; Elites; Conservatism

\section{Cultural capital in social and cultural geography}

Bourdieu's theory of cultural capital is often applied in studies of neighbourhood status (Bridge, 2001; 2006). Studies of deprived neighbourhoods often examine whether and how neighbourhood stigma or habitus - both aspects of cultural capital - can exacerbate the social disadvantage of residents (Kelaher et al., 2010; Arthurson, 2013; Richardson and Skott-Myhre, 2011). But there is also growing interest in the advantages of those living in affluent and prestige neighbourhoods (Holmqvist, 2017; Atkinson, 2016; Pow, 2011). Studies of elite neighbourhoods are linked to the rising interest in the geographies of the super-rich (Hay, 2013). This body of literature is concerned with the spatial lives of the super-rich in an increasingly polarised world: on the one hand, their weightless hyper-mobility through global 'fast spaces' and their transnational networks (Short, 2013: 35; Hay, 2013: 8; Beaverstock et al., 2004: 403-5); on the other hand, the exclusionary - often gated - superrich enclaves in selected 'Alpha Territories' in cities (Atkinson et al., 2017; Forrest et al., 2017). 
The prestige of a neighbourhood can be understood as an interplay between three types of cultural capital: embodied, objectified and institutionalised (Bridge, 2006). Embodied cultural capital is inscribed in people's bodies and minds (Bourdieu, 1986). This includes Bourdieu's concept of habitus: a set of deeply ingrained habits, skills, tastes and dispositions which determine people's capacity to navigate different social environments (or 'fields' in Bourdieu's lexicon). The neighbourhood can be understood as both an institution in which people learn and develop a habitus, and a 'field' in which one's existing habitus determines their success. For example, in the context of marginalised black American neighbourhoods (the 'hood'), Richardson and Skott-Myhre (2011, p. 11) argue that the "habitus of the hood plays a crucial role in teaching residents what is and is not acceptable, achievable, and dreamable".

Cultural capital embedded in objects external to one's body is defined by Bourdieu (1986) as objectified cultural capital. Objectified capital can be more easily transmitted from one person to another, through exchange of valued objects. However, to fully appropriate objectified cultural capital, one must have the relevant embodied cultural capital, such as a refined taste for acquiring objects that confer status and using them properly.

Institutionalized cultural capital is "a certificate of cultural competence which confers on its holder a conventional, constant, legally guaranteed value with respect to culture" (Bourdieu, 1986). Applying these concepts to analyse neighbourhood cultural capital, Bridge (2006, p. 728) found that in gentrified neighbourhoods, objectified cultural capital appears strong, in the form of a 'gentrification aesthetic' that is distinct from both conventional suburban middle-class taste and inner-city working-class taste. However, the institutionalised cultural capital of local schools is perceived by many gentrifiers as low.

The distinction of a neighbourhood can be transmitted to residents in ways that reinforce their privilege. For example, in Holmqvist's (2017) study of the affluent neighbourhood of Djursholm in Stockholm, he argues that the neighbourhood exudes a certain aura "of grandness, nobility and majesty" (p. 256-7). The wealthy residents of the neighbourhood become imbued with that aura, which elevates them from "mere mortals into leaders" ( $p$. 85).

In this paper, I examine residents' practices of both producing their neighbourhood's prestige, and appropriating it as their own cultural capital. The paper draws on in-depth interviews with 46 residents of three of Australia's most affluent suburbs ${ }^{1}$ : Mosman (Sydney), Toorak (Melbourne) and Cottesloe (Perth). This empirical analysis is presented in four main sections. The first discusses the way the prestige of elite neighbourhoods is perceived and 'measured' by their residents, pointing to the complex discourses of classification and stratification of neighbourhoods within and across cities. The second

\footnotetext{
${ }^{1}$ In Australia, the term 'suburb' (or the official term 'state suburb') is used to describe neighbourhoods regardless of their residential density or metropolitan centrality.

Accepted version of: Wiesel, I. (2018). Producing and appropriating neighbourhood prestige: cultural capital in Australia's elite suburbs. Social \& Cultural Geography, 1-26.

https://www.tandfonline.com/doi/abs/10.1080/14649365.2018.1541249
} 
section examines elite suburbs' changing lifestyles and consumption habits as contested performances of distinction. The third section considers everyday conservatism as a critical element of the three elite suburbs' habitus. The fourth section analyses the transmission of a neighbourhood's prestige onto its residents, noting the uneven ways in which this occurs across social differences such as gender and age. Prior to this detailed empirical analysis, I discuss some of the critiques and debates surrounding the application of cultural capital theory in geography; present some necessary contextual information about the three suburbs; and, briefly describe the research methods. In the paper's concluding section, I offer key lessons on the translation of Bourdieu's cultural capital thinking to social and cultural geography, and elite geographies more specifically.

\section{Applying 'cultural capital' in neighbourhood studies: three points of contention}

Bourdieu's cultural capital theory is permeated in spatial thinking: from the corporeal nature of embodied and objectified capital, to the centrality of a spatial metaphor ('field') that relates to social and physical space in complex ways (Hanquinet et al., 2012). However, as noted by Painter (2000), "attempts to 'think Bourdieu spatially' will require critical engagements with his work rather than any straightforward 'geographical translation' of the framework" (Painter, 2000, p. 256). In this section I highlight three critical challenges with such translation.

Firstly, in Bourdieu's theory, cultural practice is understood as driven by instrumentalist 'utility maximization', whereby the acquisition of social status is the ultimate end of any cultural practice. This approach represents a "rational-actor model of social life, with its individual calculating agents" (Painter, 2000) which critical social and cultural geographers tend to reject. At the same time, Bourdieu's insistence that habitus drives cultural practice that is mostly habitual rather than intentional, appears contradictory to the notion of calculated utility maximization. Additionally, it implies a "passive view of human agency" (Bridge, 2001, p. 207) which is also in disjuncture with critical social and cultural geography. Bridge (2001, p. 209) evokes rational action theory to resolve the agency conundrum in Bourdieu's theory. He argues that the 'utility' individuals pursue through cultural practice, encompasses more than economic interests and the acquisition of superior social class position.

Secondly, the framing of cultural practice exclusively in terms of the performance of social class identities, ignores the importance of other social differences which can be just as significant in identities and life trajectories. Rather than a unitary and all-encompassing identity, studies have turned to examine the intersection of class with other identity categories such as race, gender and sexuality (Walby et al., 2012, p. 231). Furthermore, elites are more likely to explain their cultural practices as expressions of individualism than adherence to collective class identity (Ollivier, 2008). 
The third translation challenge concerns the ambiguous and under-developed spatiality in Bourdieu's theory. Bridge (2001, p. 215) pointed out Bourdieu's privileging of time over space in the ordering of social processes. For example, Bourdieu emphasises the strength of cultural capitals that cannot be acquired instantly as powerful mechanism of distinction and exclusion (Bourdieu, 1984; 1986). Furthermore, although a spatial metaphor, the concept of 'field' in Bourdieu's writing refers to social rather than physical space. Nevertheless, physical space is significant too in Bourdieu's theory. Objectified and embodied cultural capital are inevitably 'fixed' in physical space (from bodies to neighbourhoods). Thus, claims to distinction are inevitably entangled in claims to location, and "the relational power struggles they illuminate cannot but be marked in the urban landscape itself" (Hanquinet et al., 2012, p. 513). Therefore, although fields and cultural capital can never be entirely reduced to fixed bounded places, they are also entangled in such spaces in complex ways. As proposed by Savage (2011, p. 518):

Rather than assume, along with Bourdieu and Wacquant (1999), that fields are contained within national boundaries, we might more usefully explore how struggles over scale are part of field dynamics, and that situated urban case studies might be better able to probe these issues.

Indeed, the following sections offer three situated urban case studies to explore the spatiality of cultural capital. This analysis suggests that distinguishing between three different phases of the cultural capital circuit - the performance, appropriation and operationalisation of distinction - can help address geographers' unease with matters of agency, social difference and spatiality in Bourdieu's theory of cultural capital.

\section{Toorak, Mosman and Cottesloe}

The suburbs selected as case studies represent three of Australia's most affluent and prestige suburbs, across three different cities (Figure 1). Sydney, Melbourne and Perth are three of Australia's most populated cities, with a combined population of over 10 million representing close to half of Australia's total population of 24 million. Despite an ongoing process of urban consolidation in recent decades (Bunker et al., 2005), Australian cities are still relatively low-density, with the majority of their population living in owner-occupied, free-standing family homes (ABS, 2016). Decades of government investment in infrastructure and services favouring the inner city have reinforced the highly centralised structure of Australian cities, and the spatial advantages of more affluent inner-suburbs. These include both longstanding elite neighbourhoods (such as Toorak and Mosman), as well as previously working-class inner-suburbs that have gentrified more recently (Wiesel et al., 2017).

For the selection of three case study suburbs, house price was used as the preliminary indicator of neighbourhood status. While Toorak is widely recognised as Melbourne's most prestige suburb, Mosman and Cottesloe occupy secondary positions in the first tier of Accepted version of: Wiesel, I. (2018). Producing and appropriating neighbourhood prestige: cultural capital in Australia's elite suburbs. Social \& Cultural Geography, 1-26. 
prestige suburbs in their cities. As noted by Beaverstock et al. (2004), studies of elite neighbourhoods tend to focus on gated communities and gentrification. In contrast, none of the three suburbs in my study are physically gated. Furthermore, Mosman and Toorak are long-established elite neighbourhoods rather than gentrified. Thus, the three case studies provide new perspectives to elite geographies.

Figure 1: Australian Capital Cities

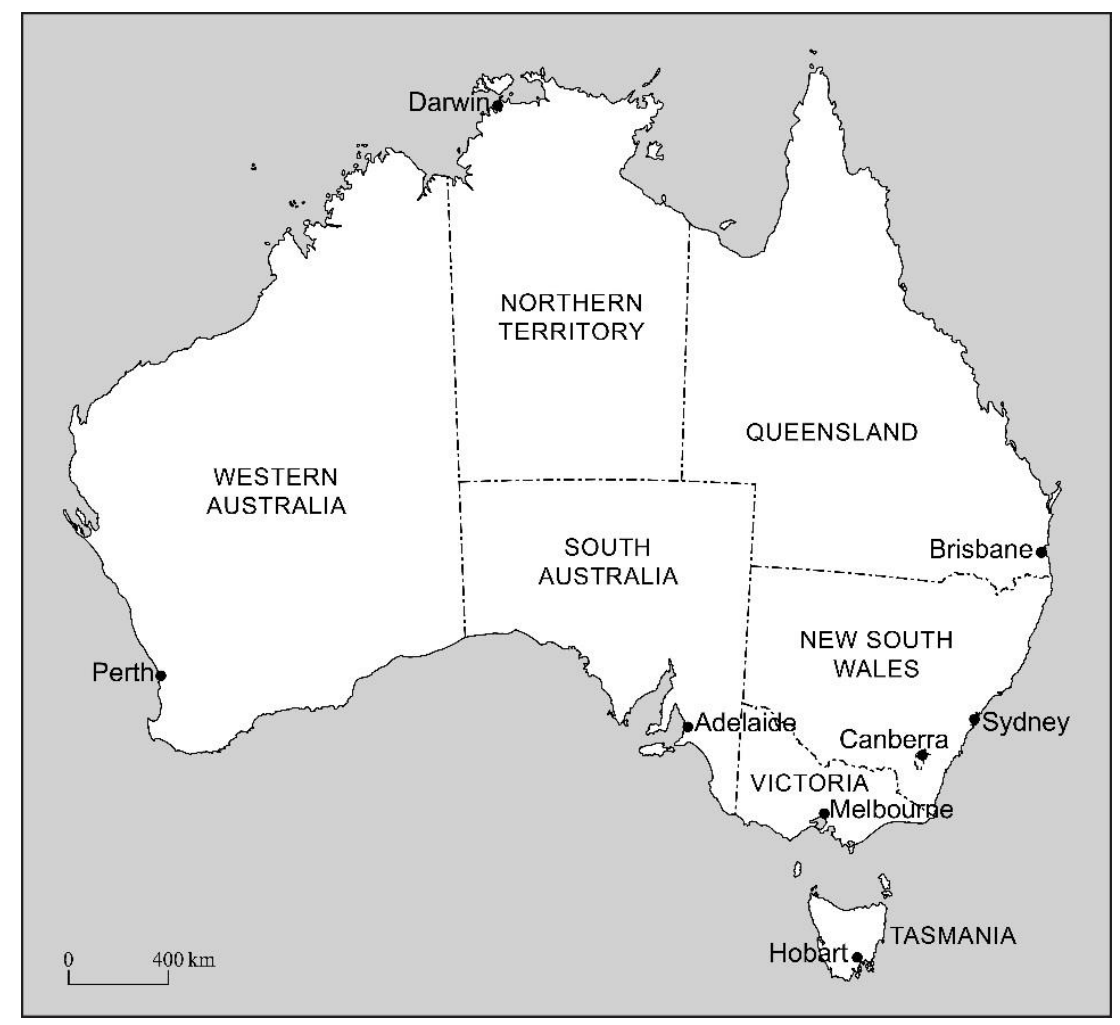

Credit: Chandra Jayasuria

Accepted version of: Wiesel, I. (2018). Producing and appropriating neighbourhood prestige: cultural capital in Australia's elite suburbs. Social \& Cultural Geography, 1-26. 
Toorak is a state suburb in Melbourne, with a population of 12,909 people recorded in the 2016 Census. Established in the 1850s, it has long sustained its status as Melbourne's wealthiest and most expensive suburb by a large margin, with a median house price of $\$ 3,400,000$ (Real Estate, 2016) as well as far more expensive historical mansions. Located on the south bank of the Yarra River, it is only $5 \mathrm{~km}$ from Melbourne CBD (Figure 2).

Figure 2: Toorak and Greater Melbourne

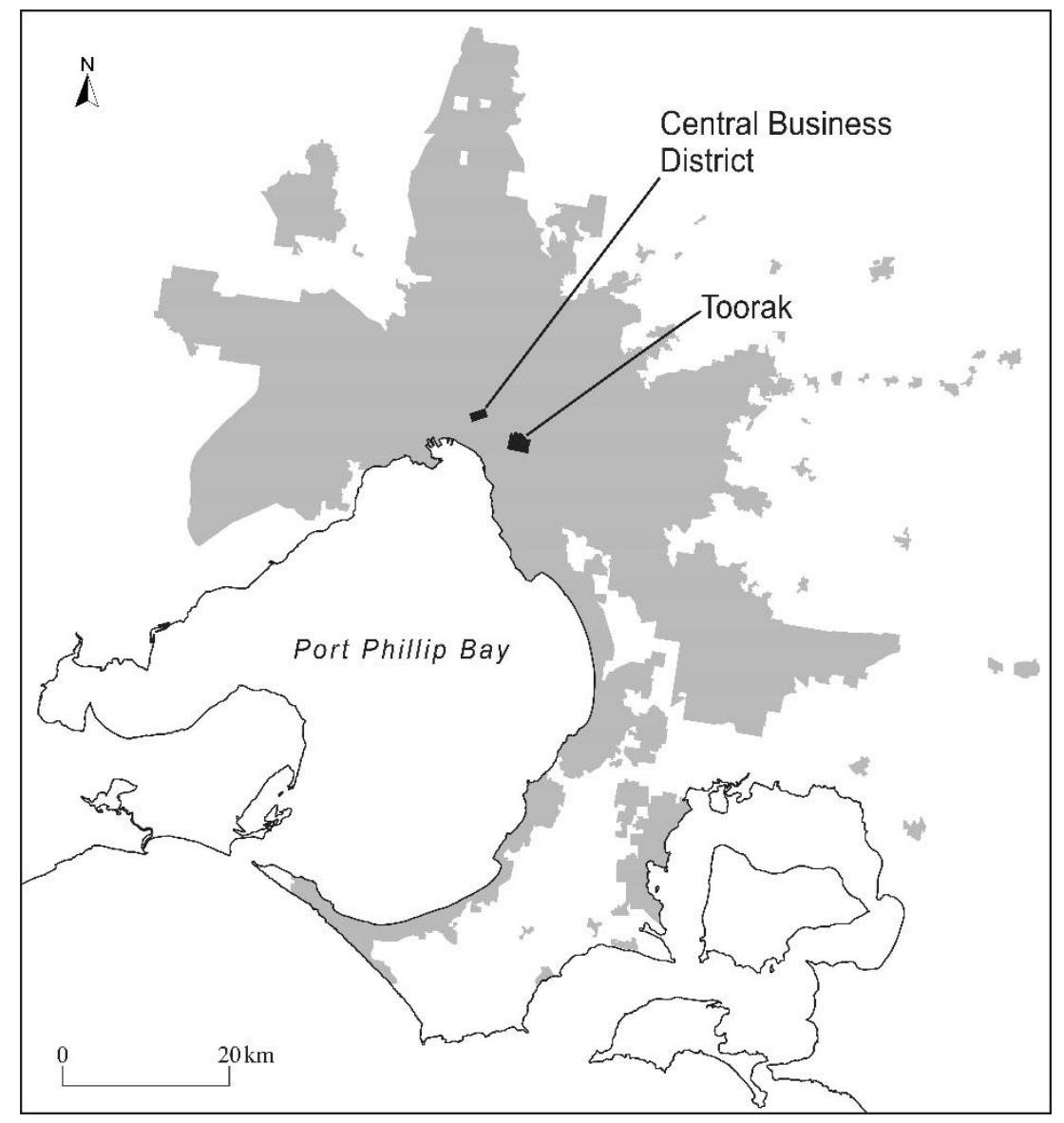

Credit: Chandra Jayasuria 
Mosman is a state suburb in Sydney, significantly larger than Toorak with a population of 28,475 recorded in the 2016 Census. Unlike Toorak, Mosman is not Sydney's premier suburb in terms of wealth, and yet it highly affluent. Its median house price of $\$ 3,100,000$ is the 6 th most expensive suburb in Sydney (Real Estate, 2016), but there are also pockets of even more extreme wealth (and property prices) within Mosman. Mosman benefits from both a central metropolitan position approximately 8km north east of the Sydney CBD (Figure 3), and spectacular Harbour beaches and views.

Figure 3: Mosman and Greater Sydney

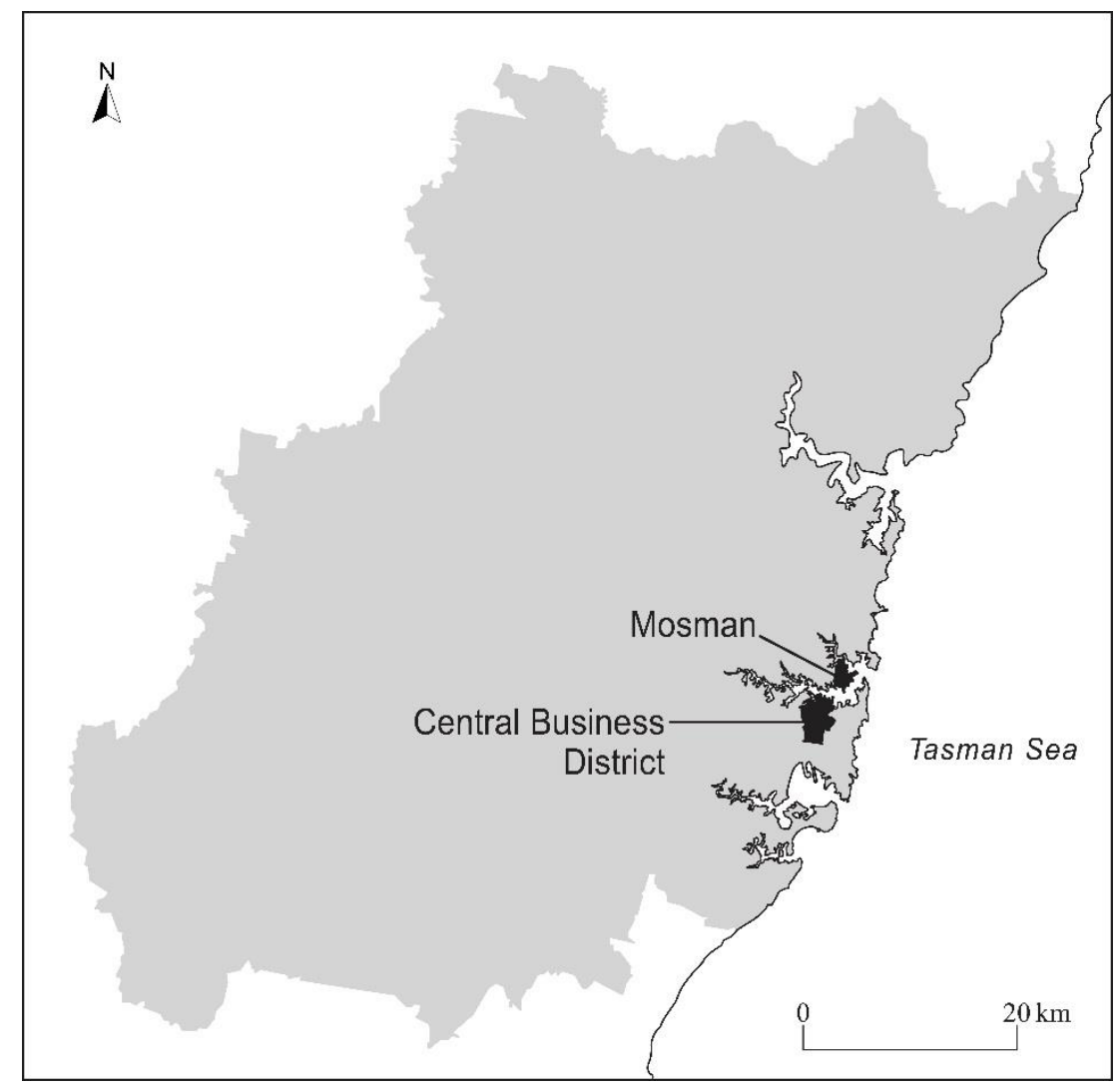

Credit: Chandra Jayasuria 
Cottesloe is a state suburb in Western Australia. Not long ago, at the height of Western Australia's mining boom in 2009, Cottesloe was Australia's most expensive suburb (followed by Mosman). Although house prices in Cottesloe have declined since then, it remains one of Perth's and Australia's most affluent and expensive suburbs, albeit less prestigious than the adjacent suburb of Peppermint Grove. Like Mosman, Cottesloe also takes pride in its popular beach (Figure 4).

Figure 4: Cottesloe and Greater Perth

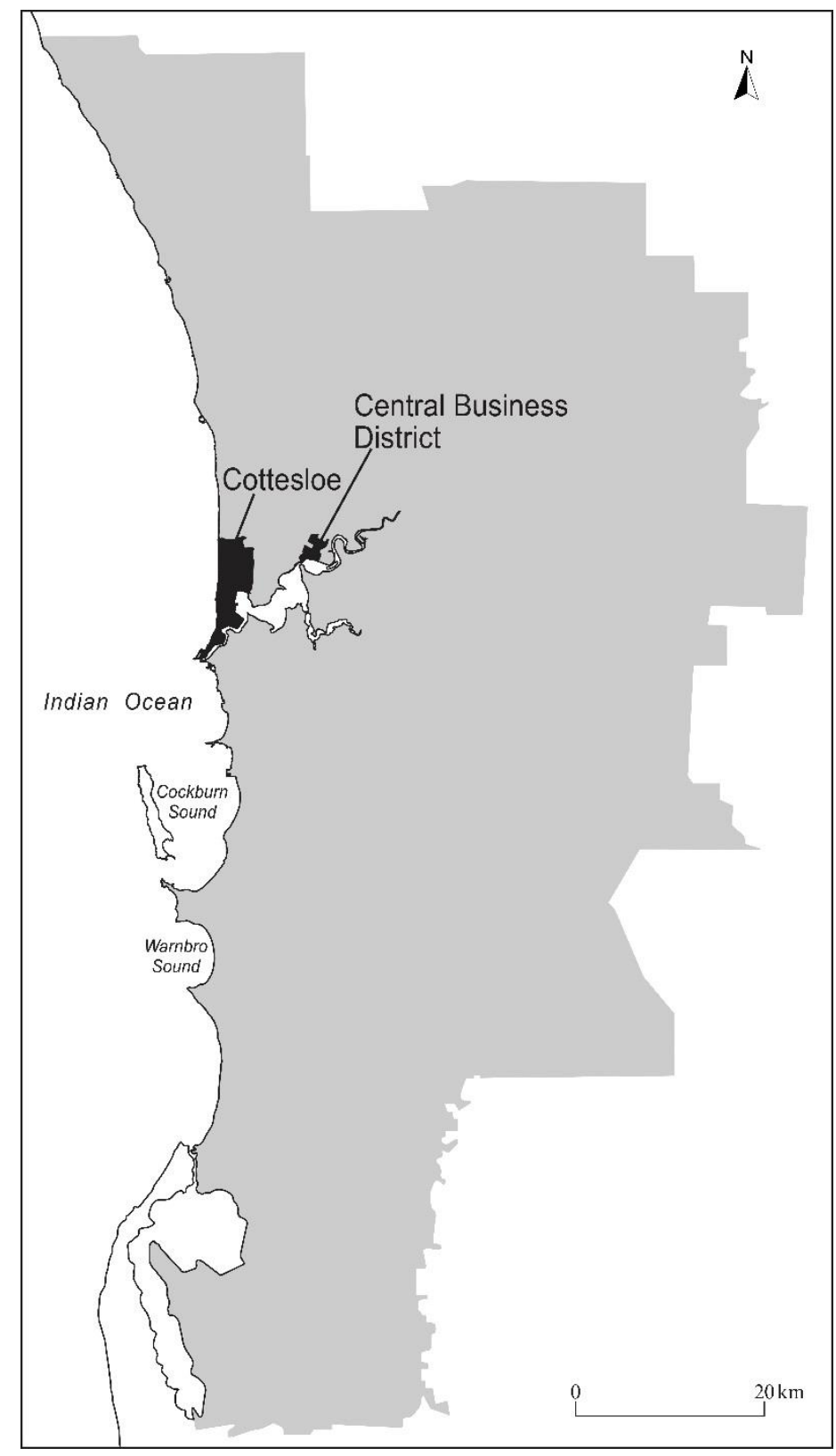

Credit: Chandra Jayasuria

Accepted version of: Wiesel, I. (2018). Producing and appropriating neighbourhood prestige: cultural capital in Australia's elite suburbs. Social \& Cultural Geography, 1-26. 
Reflecting their central metropolitan location, both Toorak and Mosman are relatively dense suburbs in Australian terms, with approximately $48-49 \%$ of their housing stock being apartments, compared to Cottesloe (19\%) and the national average (13.6\%). The three suburbs include a relatively high proportion of renters, 31-34\%, compared to the national rate of $29 \%$ (ABS, 2011).

\section{Method}

Participants for the study were recruited using a questionnaire that was distributed in 2015 to all the letterboxes covered by Australia Post's letterbox drop service in Toorak, Cottesloe and Mosman. Over a thousand people responded to the questionnaire, and of these a purposive sample of 46 participants were selected for follow up in-depth interviews in the three suburbs. Level of affluence was the primary criteria for selection of interview participants. The interviewees selected were those identified as affluent based on their income, housing and occupation. The sample represented several distinctive cohorts within Australia's elite: the owners of large and small businesses; the managerial elite of senior industry leaders; and relatively affluent 'creative-class' workers, mostly in the finance industry. Participants were included in these groups even if they had already retired. Other participants who were less affluent or in less senior institutional positions were included too if, based on their survey responses, they were identified as either well connected in elite social circles (e.g. having friends in senior positions) or strongly involved in local urban planning affairs.

Most participants were Australian born. The sample was skewed towards older participants (20 over 65 years old, 18 between 45-64, 6 between 30-44, and 2 between 18-29), reflecting the relatively older age profile of the suburbs but also higher interest and availability among retired residents to participate in an interview. The number of interviews undertaken in Mosman (23) was about twice as high as Cottesloe (11) and Toorak (12), reflecting the difference in the suburbs' population. 26 participants were male and 20 female.

The interviews were semi-structured, typically one hour long each, either in participants' home or a nearby café (and in one case a participant's boat). A range of themes were covered in the interviews, including two issues specifically addressed in this paper: residents' perceptions of their neighbourhood's status, character and lifestyle; and their experiences in presenting themselves as residents of Toorak, Mosman or Cottesloe to other people. 


\section{Suburban hierarchies}

Rather than a static top position in a linear hierarchy, the prestige of an elite suburb is more dynamic and diffuse, operating across multiples scales and social hierarchies. when asked to describe the character of their suburb, participants often described and rated it in comparison with other suburbs in the same city or elsewhere, in relation to diverse criteria. Toorak was framed by residents I interviewed as Melbourne's premier suburb, the place for people who gained their distinction either through lineage or their own successful careers. Mosman, although not the wealthiest Sydney suburb, occupied the niche of a more conservative, family-oriented and yet spectacular suburb, contrasted with other elite suburbs in Sydney's eastern beaches characterised as artsy, sophisticated, and bohemian. Cottesloe occupied a similar niche in Perth: family-oriented, conservative and beautiful, and yet outshined by the adjacent suburb of Peppermint Grove.

Each elite neighbourhood I my study had an imaginary 'twin' that occupied a similar niche in another city:

\section{I don't think Toorak's equivalent [to Mosman]. Toorak's more expensive than Mosman... I liken Toorak to Bellevue Hill [in Sydney]. (Nicole, Mosman) \\ Cottesloe is much more like Brighton [in Melbourne] (Catherine, Cottesloe)}

These narratives disclosed a subtle rivalry between elite neighbourhoods within and across cities. The typical criteria featuring in such hierarchies of elite suburbs were the price of properties, the wealth of residents and the neighbourhood's international standing or 'magnetism' as implied in Craig's words below:

\footnotetext{
Very few people who are moving from Germany to go to Cottesloe. It's not - it doesn't have that magnetism. People are moving into Peppermint Grove to do that because that's another level up in supposed status. Several levels up depending on where [which street] you are. (Craig, Cottesloe)
}

For many residents of Toorak, Cottesloe and Mosman, what makes their neighbourhood stand out compared to other elite suburbs is their unique 'atmosphere' or 'ambience'. Toorak's distinctive atmosphere was attributed by many residents to its large houses, historical heritage and trees. For Mosman and Cottesloe residents, the beach was the most significant element of their neighbourhood's distinction. Many residents' lifestyles are closely attuned to the beach, and they spend much of their leisure time swimming, walking or exercising on the beach, eating and drinking in beachside cafes, or viewing the water from the windows in their own homes. These activities suit the healthy, sociable, and sportive lifestyle many residents of Mosman and Cottesloe cherish. At the same time, this lifestyle can also be interpreted as a practice of 'appropriating' the prestige associated with the beach and the suburb as integral elements of one's own identity.

Accepted version of: Wiesel, I. (2018). Producing and appropriating neighbourhood prestige: cultural capital in Australia's elite suburbs. Social \& Cultural Geography, 1-26. https://www.tandfonline.com/doi/abs/10.1080/14649365.2018.1541249 
Yet, an elite neighbourhood's prestige is defined not by a single attribute, but a whole package or assemblage of attributes: neighbourhood character, including its social composition, amenities and atmosphere; and accessibility to work and services. For less affluent people in other parts of the city, affordability factors constrain neighbourhood choices, and therefore trade-offs and compromises on some neighbourhood attributes are inevitable. The wealthy, however, face fewer if any housing affordability constraints, and are therefore not compelled to compromise and trade-off one factor over the other. Housing choice, then, becomes a search for the 'perfect' home and neighbourhood that 'ticks all boxes':

It [Mosman] chose me...It ticked all my boxes in relation to what it had to offer (Eleanor, Mosman)

I've always wanted to live in Cottesloe, ever since we arrived in Perth. Fabulous suburb. It's got everything. (Catherine, Cottesloe)

Indeed Mosman, Toorak and Cottesloe offer a wholesome package of distinction: large houses, prestige schools, convenient and fast access to the CBD, attractive natural and built environments, a high-status social composition (described in terms such as 'likemindedness' and 'good reputation'), and multiple entertainment options.

Yet, the prestige of these elite neighbourhoods was perceived by residents as always threatened by competition from 'aspirational' suburbs lower in the hierarchy:

Malvern ...sort of taken over. It's become the new Toorak, like there's all new trendy shops. (Jenny, Toorak)

The 'aspirational' label - applied to both people and neighbourhoods - was a dominant feature in the lexicon of Toorak, Mosman and Cottesloe residents. For example, Toorak was described by some as non-aspirational, because it was only accessible to people who have already achieved the highest possible distinction, and as a neighbourhood has maintained its top status for a very long time.

I actually find people who I live around here and interact with to be more down to earth than some of the people I met down in Albert Park, the middle part of St Kilda. So maybe people [in Toorak] don't have anything to prove. (Barbara, Toorak)

But for others, even a neighbourhood like Toorak had an aspirational element to it, since it attracted aspirational individuals who had acquired substantial wealth (economic capital) but lacked the recognition (or cultural capital) associated with old money families. Andrea, 
for example, suggested moving into Toorak was an 'inevitable' pathway for a person who's achieved enormous economic wealth that they simply can no longer settle for second best.

\section{If you just sold your company for $\$ 400$ million you're not going to go and live in \\ Werribee or Frankston, you're going to come to Toorak. That's an inevitable sort of status thing...people would come here for status. (Andrea, Toorak)}

Comparisons of status operated not only between neighbourhoods, but also within each neighbourhood, where residents compared different streets on varied scales of status and character.

Here people are more conservative and are a lot more judgemental. They look at which street you live in. They don't talk about it but you can feel it. Not blatantly, but very diplomatically. 'Which part of Mosman do you live in? Which street? Which part of the street? Close to Taronga Zoo, to the Bay area or to Military road' ... You get it at the pub. [Or] if you strike a conversation with someone at Balmoral [beach]. (Kenneth, Mosman)

They say, "oh well you live in - oh whereabouts?" ... for me it's a double banger ... because it's not just "Cottesloe" - "oh how nice" - [it's also] "John Street" - "Oh my God!” (Jane, Cottesloe)

As observed by Rose-Redwood (2008, p. 434), conflicts surrounding the naming of places represent a struggle for the symbolic capital that is objectified in these sites. A similar dynamic was evident in conflicts surrounding a local campaign to split Mosman back into the five separate suburbs which were gazetted under the umbrella of Mosman in 1996 (Balmoral Beach, Beauty Point, Mosman, Mosman Bay and Clifton Gardens). The campaign, initiated by some residents of Mosman's more prestige areas, was met with opposition from residents and business owners who considered the initiation of new suburbs unnecessarily wasteful (e.g. requiring changes to businesses' stationary). The conflict could also be interpreted as a battle for prestige: residents of Mosman's more prestige areas seeking to differentiate themselves, and those from less prestigious areas clinging to Mosman's collective prestige. Yet each side of the conflict denied any status-related motivations, while blaming the other for just that.

\section{Spaces of performance: luxury cars, mansions and shopping 'villages'}

How does cultural capital - or prestige - become spatially fixed in elite neighbourhoods? The consumption of luxury houses and cars are perhaps the most conspicuous rituals of distinction in Australian elite neighbourhoods. As observed by Veblen (1899), over a century ago, the upper class differentiates itself from lower classes through conspicuous consumption of goods that reflect choice, excess, adornment, comfort, desire and leisure Accepted version of: Wiesel, I. (2018). Producing and appropriating neighbourhood prestige: cultural capital in Australia's elite suburbs. Social \& Cultural Geography, 1-26. https://www.tandfonline.com/doi/abs/10.1080/14649365.2018.1541249 
rather than necessity, subsistence, survival and productivity. Such consumption of rare and expensive goods, is inevitably beyond the reach of lower classes, and yet sets the example and norms they seek to emulate. These objects of distinction become an important aspect of the collective 'aura' elite suburbs project to outsiders (Holmqvist, 2017). However, such performances of distinction are not merely projections to outsiders, rather are driven to a large extent by competition and attempts at differentiation between individuals and cohorts within the elite suburb.

The proximity of residents' houses and cars in the elite neighbourhood makes comparison and competition almost inevitable. Many residents feel under pressure to keep up with the joneses:

[There are] divisions along the line of the cars you drive. Sorry, but it happens. People who wouldn't be seen dead in a car like that or this ... they might have their debt maxed up to the hilt, but appearance is everything. (Jane, Cottesloe)

If you're building a new house in Cottesloe at the moment you probably have to the minimum is six cars parked underground ... A lot of people have six cars. (Craig, Cottesloe)

Come on weekends and there's people with their - they all get their Maserati's out...I go down to the beach every morning. The cars are Mercedes and Audis and BMWs.

(Denise, Mosman)

Vehicles have long been an object of competitive display among elites. As Daloz (2009, p. 73-4) points out, at time of antiquity "beautifully decorated chariots ... were significantly buried, in some places, with their deceased owner". Likewise, in the seventeenth and eighteenth centuries in Western Europe, "there was no more visible form of prestige than ornate coaches and equipage". The cultural capital that is objectified in cars is associated with ability to travel rapidly, comfortably with both privacy and style, a fine mix of functional advantages and symbolic displays of distinction.

One of my interviewees, when answering my question about his choice to move from his previous middle-class neighbourhood to Toorak, joked about the difference in how his luxury cars appeared in each of those environments:

My cars looked rather strange in [previous neighbourhood] where I lived for the previous 15 years. So I brought them all to Toorak. The Rolls Royce looked better in Toorak. (Sam, Toorak)

Sam felt more comfortable driving his Rolls Royce in Toorak, where they were less conspicuous compared to the previous neighbourhood. But for other interviewees, certain Accepted version of: Wiesel, I. (2018). Producing and appropriating neighbourhood prestige: cultural capital in Australia's elite suburbs. Social \& Cultural Geography, 1-26. https://www.tandfonline.com/doi/abs/10.1080/14649365.2018.1541249 
displays of wealth - even in an extremely affluent area like Toorak - were interpreted as Nouveau Riche lack of sophistication. In Mosman, for example, several participants were critical of ostentatious displays of wealth which they saw as antithetical to their suburb's distinctive habitus:

You see the occasional super-car cruising through Mosman, and to me it looks out of place. The driver clearly has a lot of money but that doesn't surprise me, a lot of people around here have a lot of money. What's surprising is that car in an environment where you don't have splashing displays of wealth. ... I see extraordinarily wealthy guys walking around Mosman on a weekend in daggy old shirts, and a pair of sandals. (Daryl, Mosman)

[In the past] people [in Mosman] would laugh at people who were very flash and overt. They'd just think what a loser ... There wasn't that kind of aspirational feel that there is now where people seem to declare themselves by their appearance rather than their substance, their reputation and all that stuff, which was - and their family, where they go to church and all that stuff - the authentic stuff ... but now people take - they don't get that that's vulgar ... it's more competitive in that kind of cheesy superficial way where people show [off]...They don't get it ... I don't know if they're even aware of what it was (Vicky, Mosman)

To some extent, these discourses reject the performance of distinction through consumption of objectified cultural capital (that can be immediately purchased), while valorising a more embodied distinction through habitus (which requires many years, perhaps even generations, to cultivate). Such discourses effectively differentiate between more established members of the elite, and its newcomers.

Perhaps the most contentious form of conspicuous consumption in the three suburbs was the development of large mansions. The size of dwellings - relative to those surrounding them - is often proportionate to social status. The imposing character of large mansions, the availability of space for accommodating guests, and the presence of servants who maintain these dwellings, are all performances of distinction and domination (Daloz, 2009, p. 69). However, attempts to project distinction through large mansions was ridiculed by some as transparent 'aspirational' behaviour, as opposed to authentic cultivated elite taste. In addition to expressions of poor taste - of not 'getting' the habitus of the field, as Vicky claims in the quote above - large mansions were also criticised for blocking the views of existing (more 'authentic') residences to the beach, a river, a park, or the city. Such views are both a lifestyle perk, and an important objectified cultural capital. Thus, a great deal of local tension and dispute in elite suburbs now concerns big houses blocking such views. 
In Mosman, large mansions began to appear from the 1980s onwards:

A few were modern replicas of Edwardian mansions, but the true seigneurial idiom of the 1980s was more temple-like: massive, flat-topped, pillared, high walled, securely gated, and usually painted in some pastel colour. These megahouses, as they became known, invariably faced the harbour (Souter, 1994, p. 324).

In Toorak, large mansions were a persistent feature of the landscape throughout the suburb's history. Rather than criticise the size of new mansions, some established residents mocked their Neo-Georgian architecture as a transparent replica of more authentic prestige.

However, rather than build new Neo-Georgian mansions, some of Toorak's 'new money' residents purchased the old mansions of well-known old money families. Such mansions fall in Paris's (2017, p. 253) classification of trophy homes, which are equivalent in many ways to unique artworks. Acquiring old mansions could be interpreted as a strategy to acquire the objectified cultural capital associated with their former 'old money' owners. As observed by Jager (1986) - in the context of Melbourne's gentrified inner-city neighbourhoods - the consumption of older houses with a perceived heritage value serves the appropriation of the present space and its future equity, as well as its history, as a practice of distinction. This practice cannot be easily dismissed by established elites as reflecting poor taste, yet although the object itself was authentic, its purchase by owners who lack the appropriate embodied cultural capital was still ridiculed as 'aspirational':

\footnotetext{
The original [famous super-rich family] people lived there... Now it's been bought by a young ... man who ... build up a ... company and sold it for $\$ 400$ million. He just spent ...\$17 million buying that house and putting $\$ 10$ million into it [renovations]. ... is his life going to be better? No, probably - well he's going to feel better about himself because he'll feel prestigious. His friends will go there, they'll have parties. I mean it's that aspirational thing. (Andrea, Toorak)
}

The importance of material consumption as a performance of status would suggest elite suburbs will become havens for luxury goods retail. In Mosman, the council's planning regulations enforced its preference for smaller boutique shops in outdoor shopping strips (or 'villages' in contemporary urban planning lexicon) over larger but less luxurious shopping centres. Some residents complained about the sacrifice of everyday convenience for the sake of status and the 'village' atmosphere encapsulated in such boutique shops.

There's a lack of facilities in the area, there's a lack of shops ... there's no Woolworths or Coles [large supermarket chains] ....The council has never allowed development here, because they're trying desperately to make it, keep it a village

(Denise, Mosman)

Accepted version of: Wiesel, I. (2018). Producing and appropriating neighbourhood prestige: cultural capital in Australia's elite suburbs. Social \& Cultural Geography, 1-26. https://www.tandfonline.com/doi/abs/10.1080/14649365.2018.1541249 
There was a proposal to put a big supermarket ... and the council knocked it back ... they want to protect these smaller shops ... Not everyone wants to shop in women's clothing boutiques all day. Ninety per cent of Mosman shops are women's clothing boutiques (Brendan, Mosman)

When visiting Toorak for the first time, my personal impression was that the small Toorak Village shopping strip with cafes and boutique shops was pleasant, but unremarkable as one might expect from the most prestigious suburb in Melbourne. Some residents I spoke to shared my view, and explained that small boutique shops in Toorak Village were dying partly because of the entry of a large supermarket:

About 18 months ago I came around to the village area and did a little survey. There were 16 shops for lease and I thought that was just tragic .... You had a proper baker and you had a proper butcher and you had about five chemists ... You had these little comfortable boutique places. ... now you've got the supermarket that comes in and we've lost all that small shop feel about it.... it's so changed, so changed ... I would never buy my meat at a supermarket. You don't know how long it's been packaged for. (Monica, Toorak)

Monica's comment on the 'tragic' decline of the village points to a deeper angst. Apart from competition with supermarkets, the decline of Toorak Village reflects perhaps a wider change in the cultural capital of Melbourne's elites. The retirees of Toorak spend less, and younger people now choose the trendier nearby Hawksburn Village for its 'buzz', over the old Toorak Village for its 'class'.

Hawksburn has become flasher... The younger ones go and they all spend money like water. (Lesley, Toorak)

The notion that claims for distinction are increasingly made through individualistic choice from a range of cultural options, as opposed to collective upper-class adherence to a limited range of highbrow options (Ollivier, 2011, p. 30-1) can explain this shift from consumption in once highbrow Toorak Village to the more eclectic Hawksburn Village nearby. The status of younger residents of Toorak is performed through their economic capacity to 'spend money like water', as well as their sophistication as trendy consumers unrestricted by traditional highbrow culture.

Nevertheless, statistical analysis of the survey results from the three suburbs - to be reported in more detail elsewhere (Author, forthcoming) - indicated that highbrow cultural capital was still an important practice of distinction in Australia's elite suburbs. People participating in highbrow cultural activities - attending theatres and classical concerts, art collection and membership in private member clubs - were almost twice as likely to have

Accepted version of: Wiesel, I. (2018). Producing and appropriating neighbourhood prestige: cultural capital in Australia's elite suburbs. Social \& Cultural Geography, 1-26. https://www.tandfonline.com/doi/abs/10.1080/14649365.2018.1541249 
friends in positions of power (such as Members of Parliament, and owners or Chief Executive Officers of business).

Cultural capital becomes 'spatially fixed' when practices of distinction become associated with a place. In the case of Toorak, Mosman and Cottesloe, this process did not involve a collective performance of a commonly accepted shared habitus; on the contrary, these neighbourhoods' collective cultural capital is the product of tension and competition between different cohorts within the elite (old money versus new money; younger versus older generations) negotiating diverse - at times conflicting - performances of distinction (high-brow, conspicuous, eclectic). And yet, such competition and tension within elite neighbourhoods, rather than dilute their collective aura, can charge it with energy.

\section{Everyday conservatism}

In Bourdieu's (1986) theory, distinction is projected not only through possession of objectified cultural capital (such as mansions or luxury cars), but also through one's embodied cultural capital or habitus. An elite habitus can include, for example, a refined taste in art, a certain bodily appearance (e.g. pale skin for the Victorian nobility), or an accent or dialect. However, as evident in the previous section, there is no single Australian elite habitus, rather several competing versions that do not always co-exist harmonically in the same neighbourhood. However, one habitus shared among most residents of Mosman, Toorak and Cottesloe is their conservatism, as both a political ideology and set of everyday practices. Although not as glamourous as the French Petit Bourgois habitus documented by Bourdieu (1979; 1986), and by no means unique to elites, Australian elite suburb conservatism serves their distinction in important ways.

Many residents of Mosman, Toorak and Cottesloe spoke of conservatism as a shared value that to some extent defines their local community. Some participants considered it only natural that a suburb with a concentration of wealthy people would also be highly conservative:

\footnotetext{
People that live there can afford to live there. They can afford to live there because they are wealthy or creating wealth, which is a very capitalist way of looking at society. (Eleanor, Mosman)
}

Others were attracted to these neighbourhoods precisely because of their reputation as conservative communities. Over the years, these shared values continued to underpin their sense of belonging in the neighbourhood.

Moved to Mosman in 2000... I think it was fundamentally about trying to find a suburb similar to the one I grew up in as a child myself. So that it was safe, common or shared values with your neighbours. And that probably reflected, at the time, the Accepted version of: Wiesel, I. (2018). Producing and appropriating neighbourhood prestige: cultural capital in Australia's elite suburbs. Social \& Cultural Geography, 1-26. https://www.tandfonline.com/doi/abs/10.1080/14649365.2018.1541249 
political association that I held that could be broadly classified as being a conservative small-1 liberal. (Daryl, Mosman)

People's aspirations and standards are similar ... One of the joys of living here, you are living in an environment whereby your immediate neighbours and contacts, whether it's on the beach in the morning or in the restaurants or just parking next to people in the shops, come from a similar socio-economic group with similar values. (John, Mosman)

Conservatism, as a political doctrine, involves preference for maintaining the status-quo and expanding the free-market while minimising state intervention. These ideologies are premised on respect for tradition and a view that progress is achieved through organic incremental development rather than state-driven transformation (O'Hara, 2012; Honderich, 2005).

Family values are also at the core of the conservative paradigm. The traditional heteronormative family is understood in conservative thinking as the foundation of society, as explained by O'Hara (2012, p. 172):

The traditional family, whatever form it takes, is very important to the conservative. It typically takes on great social burdens of childcare, care for the elderly, health care, mental health care, social security, welfare and education, to name but a few, and furthermore does this in ways that are acceptable to most citizens. ... as well as the support, love, intimacy and nurturing that most people give and receive through family structures... Changes to the family will have an immense impact across society, with many unpredictable consequences.

The conservatism of Cottesloe, Mosman and Toorak underpins their allegiance to the Liberal Party in national Australian politics, and their electorates districts have long been considered 'Blue Ribbon' seats where Liberal (or National) victories are almost guaranteed.

I just feel sorry for the ALP [Australian Labor Party] member handing out leaflets.

(Roger, Mosman)

Beyond election day, the conservatism of the three elite suburbs is also performed in their everyday life and constitutes a major part of their habitus.

An uneasy engagement with ethnic or racial diversity is a significant expression of elite suburbs' everyday conservatism. Residents in Mosman, Toorak and Cottesloe typically rejected the view that their suburb is culturally homogenous, often emphasising the diversity of European cultures represented in the suburb as a form of cosmopolitanism.

Accepted version of: Wiesel, I. (2018). Producing and appropriating neighbourhood prestige: cultural capital in Australia's elite suburbs. Social \& Cultural Geography, 1-26. https://www.tandfonline.com/doi/abs/10.1080/14649365.2018.1541249 
Whereas such European or White cosmopolitanism was embraced or taken for granted, the presence of non-Whites - in recent years primarily residents of Asian or Chinese ancestry was viewed as an anomaly and a source of discomfort. Some participants emphasised their shared social class identity with more recently arrived Chinese residents as "hard working professionals", which they felt bridged across racial or cultural differences between them. However, for many others - especially in Mosman and Toorak - the Whiteness of their suburb was perceived as being threatened by an influx of 'Chinese' or 'Asian' families and property investors. They were singled out, their intentions were questioned, and concerns were raised about Chinese buyers eventually leaving houses vacant, threatening to create a 'ghost town', on the one hand; or over-population and over-densification, on the other hand. New Chinese owners and developers were perceived as lacking any attachment to the local heritage value of historical houses as well as trees, which are being demolished and replaced (Author, 2017).

In addition to their defensive Whiteness, elite suburb residents (especially in Mosman and Toorak) described their neighbourhoods as highly controlled environments, where accepted public behaviour codes were closely enforced both formally (e.g. by the local council) and organically through self-regulation by other members of the community. In this orderly environment, even the most minor transgressions of order lead to an immediate reaction:

This suburb would have to be the cleanest and people would have to be the most organised in terms of picking up dog poo, and always walking around with baggies that I've ever come across. If you don't, a ranger's going to get you, because it's a bit of a nanny state here as well. Or whoever's walking past will tell you to do the right thing. So it really is that sort of place. (Denise, Mosman)

You don't get trouble, and if you do get trouble I discovered that people get very quickly on to that. It's kind of like a village that works together. (Kenneth, Mosman)

Several participants in Mosman commented with some irony that even very minor violations of the accepted order tend to become front page material in Mosman's local newspaper. Such everyday conservatism was described as 'petty' and 'entrenched':

Some of the viewpoints that are expressed, particularly in letters [to the Mosman Daily], are so - not extreme but what are they?... entrenched. That's the word I'm looking for. ... It's usually very, very conservative [laughs] and not very tolerant [laughs]. ...So you can make something almost out of nothing through the Mosman Daily and it's a bit of fun. (Scott, Mosman) 
However, the norms of politeness and civility in everyday interactions were considered by some as a 'thin veneer' that masks aggressive competition that becomes apparent in planning conflicts:

In some ways people expect to be polite and they expect a minimum level of courtesy ... But at times, that's a very thin veneer. There's a competitiveness and a double standard that operates in Cottesloe that is pretty unpleasant [underneath] its surface. ... the key area to see it almost every meeting is at the Town Council to watch the development applications go through. (Jane, Cottesloe)

The demographic - wealthy, moderately wealthy, quite wealthy people ... It's a comfortable, cosy - a very dear friend of mine used to use the term, a fur-lined mouse trap [laughs]. Mm, very cosy, but beware. (Roger, Mosman)

Another aspect of the localised, everyday conservatism of elite suburbs, is their discomfort with change, and willingness to 'arc up' to defend the status-quo:

[Cottesloe is] quite conservative I would suppose. We like our peace and quiet. We arc up. We are arcing up at the moment with the prospect of the big trucks being diverted through .... We enjoy our little bit of paradise I suppose and we don't want it ruined. (Catherine, Cottesloe)

'Arcing up' against perceived threats can be understood as a strategy to defend the neighbourhood's cultural capital. As observed by Deverteuil (2013, p. 601), NIMBY (Not In My Backyard) activism in cities is entangled with class-based conflict, and "remains burdened by an exclusionary tendency on behalf of privileged groups". Thus, such conservatism can be understood both as a protection of the neighbourhood's cultural capital, and an integral part of this habitus in and of itself.

The conservatism of residents was also mirrored by the conservatism of the local council. In Cottesloe, for example, some residents described the council's default initial response to any development proposal as resistance. Indeed, a recent newspaper article (Gladstone, 2018) reported that 12 percent of Development Applications in Mosman have been decline - the highest proportion in metropolitan Sydney - compared to about 1 percent in some of the less affluent councils.

The three suburbs were also perceived by their residents as reflecting conservative family values. This involved the normalization of heteronormative families where males act as breadwinners, and females have a significant role in family rearing often while working parttime or less. Communal interests were portrayed as secondary to investment in the private 
family home, breadwinning or children-related communal activism (such as volunteering in schools and junior sports clubs).

The home - specifically the owner-occupied, single-family detached house or mansion - is the material representation of the family in elite suburbs. Ownership represents the stability of the family, and the detached form of the house represents the nuclear family's status as an autonomous cell in society. The large homes of elite suburbs were portrayed by residents as secure and relatively self-sufficient environments for families, allowing minimal engagement with the outside world:

\footnotetext{
As soon as I drive into my garage at night I've got my environment. I don't need to make anything - to improve anything else. I've created my environment on my 600 square metre block and that's my home. Well, instead of going out, people would have people over to their houses, because houses are generally probably bigger than they would be in Melbourne and Sydney. (Brian, Cottesloe)
}

The centrality of the heteronormative nuclear family in everyday conservatism, means young families (mostly parents in their 30-40s living with children) have a 'highly approved' status in the elite suburb:

When I say divisions, I don't necessarily mean these are unbridgeable divisions. But there certainly is I think a division between people who are married and have children and that is highly approved (Jane, Cottesloe)

In Cottesloe and Toorak residents spoke about recent processes of 'renewal' with a wave of younger affluent families entering the suburbs as new residents. At the same time, these neighbourhoods have an older age profile relative to their respective metropolises, due in part to the rising costs of housing which exclude younger and less financially established families. The celebration of young families, is thus also coupled with discourses associating population ageing with the 'decline' of the elite suburb, and its loss of vitality (as discussed in the previous section).

Although several participants in my study - indeed a very small minority - remained resistant to their suburb's conservatism, by and large such everyday conservatism was a significant unifying collective habitus of the three neighbourhoods. Everyday conservatism is by no means unique to elites, and it is not a characteristic of all elites or elite suburbs. Nevertheless, in concert with other markers of distinction, everyday conservatism demarcates the boundaries of inclusion and exclusion of these elite neighbourhoods' distinction. Those who do not share the habitus of everyday conservatism - or are singled out by it as Others - will struggle to gain recognition as members of the elite neighbourhood and the privileges it confers. And while everyday conservatism cannot be explained exclusively in terms of status seeking, the discourses presented above demonstrate that Accepted version of: Wiesel, I. (2018). Producing and appropriating neighbourhood prestige: cultural capital in Australia's elite suburbs. Social \& Cultural Geography, 1-26. https://www.tandfonline.com/doi/abs/10.1080/14649365.2018.1541249 
contemporary Australian elites are conscious of the direct connection between conservatism - as both a political ideology and an everyday practice - and the conservation of their advantage and distinction in a capitalist society.

\section{Spaces of operationalisation: distinction and stigma}

Cultural capital can be spatially fixed in elite neighbourhoods, albeit with two important caveats. Firstly, rather than a 'neighbourhood effect' that applies equally to all residents, there is significant variation within the neighbourhood in the capacity of individual residents to appropriate its prestige as their own capital. Secondly, there is significant variation the effects of elite neighbourhoods' cultural capital across different 'fields'.

Participants in my study tended to play down the advantages associated with their recognition as elite suburb residents. However, some pointed to particular situations (or 'fields' in Bourdieu's lexicon) in which these advantages can be pursued.

There was perception that being known as an elite suburb resident does provide certain advantages in communications with others. Indeed, one long-term resident commented on a common practice in a pre-internet era, whereby people living outside the suburb often acquired a Toorak post box as their primary address.

Well if you've got an address in Toorak people are much more likely to respond to any mail or they were when mail was the thing. I don't know about emails now, it probably cancels that out a bit. (Monica, Toorak)

If being resident of an elite suburb was a status symbol, having been born in the suburb was described by one participant as an even higher status symbol. One participant who was born in Mosman described the awe this fact inspires in some people, and as a 'bit of ammunition' she could use in communications with others, especially with more 'aspirational' Mosman residents:

Sometimes I know that when I say I'm born here it's like whoa... It's like I'm a native. That changes the tone. It's kind of handy but I don't like it ... I'm participating in that because I just - I don't - because I feel I just need that little bit of ammunition - ammunition, isn't that terrible - defence. (Vicky, Mosman)

This finding contrasts with the notion of 'elective belonging' proposed by Savage et al. (2005). Elective belonging is a discourse in which a stronger sense of belonging to a neighbourhood is attributed to those residents who have moved from elsewhere and consciously elected to move into and stay in the neighbourhood, compared to those who were born and bred there. Perhaps Mosman is different to the neighbourhoods studied by 
Savage et al. (2005), or perhaps the question of which status is superior depends on who you ask: those who moved from elsewhere, or those born and bred in the neighbourhood.

Some male participants working in the business sector noted that being recognised as a Mosman resident generated a reputation of success, financial acumen, and reliability, that was at times helpful in their careers:

I think there was always the perception that this side of the harbour ... that generally you were - you should be good for your word. (Barry, Mosman)

If I want to discuss with one of my clients, for example, it's sort of a golden star. Also in an interview or something it helps as well. I don't know, maybe it suggests I have a good background. If I live in Mosman, you must have a mansion or something. I prefer to have this golden star than to say that I'm from Blacktown or something. (Kenneth, Mosman)

However, in certain 'fields' and for certain cohorts, being known as a resident of an elite neighbourhood was more of a burden than an advantage. Although in urban studies stigma is typically associated with the poorest neighbourhoods (Kelaher et al., 2010; Arthurson, 2013), a different kind of stigma also applies to elite suburbs. While the reputation of being successful was often described as a positive effect of elite suburb residency, some participants were irritated with the assumption that they are wealthy, based only on the neighbourhood they live. They felt such labels ignore important individual or communal characteristics other than wealth. One practical negative implication of this label was the higher fees often charged by contractors for various services, an issue commented on by multiple participants in my study across the three suburbs.

Another negative label elite suburb residents felt was imposed on them was that of being 'snobby' or 'above their station':

We were down the beach the other day ... Our dog ... was just sitting on the beach and there were these two young guys trying to call him over to play with him ... One of them said oh, we thought he [the dog] must have been from Cottesloe. He was a real snob and he wouldn't come and talk to us... so there is that attitude and it's very real. I had it myself before I moved here (Rachel, Cottesloe)

A lot of my friends that don't live here, they always poke at me, you live in Mosman so you think you're better. I don't think I'm better, but that's the perception.

(Kenneth, Mosman)

Accepted version of: Wiesel, I. (2018). Producing and appropriating neighbourhood prestige: cultural capital in Australia's elite suburbs. Social \& Cultural Geography, 1-26. https://www.tandfonline.com/doi/abs/10.1080/14649365.2018.1541249 
Some residents were apprehensive of such comments because they implied that their status was inherited rather than acquired, and as such a lesser form of distinction in a capitalist society. Male residents typically rejected such comments, asserting that their elite neighbourhood residency was their 'reward' for hard earned success in a competitive capitalist economy.

I came from a poor family so I never believed that I'd ever have something like that. But I worked hard during my life and it's like a reward. (Mark, Toorak)

Like I'm proud of it - maybe a little part of me is, in a way, that I've managed to buy somewhere here, but I talk it down ... I don't go yeah, I live in Cottesloe. So I think I have that in the back of my mind and generally (Brian, Cottesloe)

These male participants often dismissed negative attitudes as being no more than expressions of envy and reflective of Australia's so-called 'tall poppy syndrome'. Some of them used humour and irony to brush off insults. Dave, for example, referred to his Cottesloe house as a 'council flat' (the British moniker for public housing), in doing so ironically conflating the contrasting stigma applied against impoverished and elite neighbourhoods.

Women and youth were more vulnerable to elite suburb stigma. A common perception was that older men are self-made successful professionals or business people (i.e. acquired wealth), whereas women and youth were living off their father's or husband's wealth (i.e. inherited wealth). In Mosman, for example, women were exposed to stereotypes of 'Mosman Moms':

There's always been the joke ... How do you know who's the Mosman woman at a funeral? She's the one wearing a black tennis dress. Mosman women only - don't work and go to lunch and drink and do all of that and Mosman women don't work. (Lisa, Mosman)

Young people (both male and female) living in elite suburbs were exposed to a 'silvertails' stereotype, which was considered harmful in dealings with outsiders:

Our son, he got a degree, he was trying to get a job and in the end we changed his address. [a relative] had him addressing his job applications [to another suburb]....That made a difference because there was actually a negative vibe about kids who live in Toorak... He got himself a job. He's worked hard ever since and that was fine, but just to get him started there was this thing about...Yeah, so it can work against you (Barbara, Toorak).

Accepted version of: Wiesel, I. (2018). Producing and appropriating neighbourhood prestige: cultural capital in Australia's elite suburbs. Social \& Cultural Geography, 1-26. https://www.tandfonline.com/doi/abs/10.1080/14649365.2018.1541249 
The labelling of young people and women affected their dealings not only with 'outsiders' to the suburb, but also with other residents of those suburbs. Unlike older men who tended to laugh off or dismiss stigma as envy, it was common for young people and women to be more sensitive, and many avoided disclosing their neighbourhood name to outsiders.

I prefer not to mention where I come from until I've got to know people more. I think most people feel that way. You don't want to be labelled (Shelly, Cottesloe)

I wouldn't let anybody know unless they asked, because that's taking away one - not that everyone judges, but... (Rachel, Cottesloe)

I don't like to say it outside of [Mosman] - because I just find it an alienating thing. ....[] Play it down. I'll say the Lower North Shore. (Vicky, Mosman)

\section{Doesn't affect me one way or the other, but it does my youngest daughter ... if somebody asks her where she's from, she won't say Mosman. ... she'll sort of say, I'm from the Northern Beaches (Candice, Mosman)}

Notwithstanding the above, while participants were aware of, and often irritated by, negative attitudes, most - regardless of age and gender - acknowledged that it was overall a 'small price' to pay for the privilege of living in an elite suburb and the many benefits it offers:
When people ask where you live and you say Cottesloe, they can attach a certain - [laughs] - preconceived idea perhaps about you. But that's a fairly small price to pay considering it is - I think we're very, very fortunate ... it is a privilege and I can understand some people feeling judgemental about that. (Shelly, Cottesloe)

Thus, the prestige of an elite neighbourhood does not equally apply to any resident, nor is equally useful as a capital in any 'field'. This understanding highlights the need for spatial analysis that examines not only the spaces in which a cultural capital is fixed in the form of neighbourhood prestige or stigma, but also the spaces where claims of distinction are made towards the purpose of material or other gains. It is often in these spaces of cultural capital conversion or operationalisation where calculated instrumental motivations become most apparent, as well as inequalities in ability to appropriate and utilise cultural capital materialise, across both social differences and varied fields.

\section{The geographies of cultural capital}

In this paper I examined how residents of three Australian elite suburbs build and sustain their neighbourhood's prestige; and, how they appropriate their neighbourhood's prestige Accepted version of: Wiesel, I. (2018). Producing and appropriating neighbourhood prestige: cultural capital in Australia's elite suburbs. Social \& Cultural Geography, 1-26. https://www.tandfonline.com/doi/abs/10.1080/14649365.2018.1541249 
as their own cultural capital. Building and sustaining the prestige of an elite neighbourhood is at the same time a collective endeavour of all residents, and a fragmented set of practices driven by tension, conflict and competition between individuals and cohorts of residents. The competitive keeping up with the joneses dynamic - for example in the consumption of oversized mansions - can be interpreted as a practice through which individuals strive to enhance their social standing, not necessarily in relation to subordinate classes, rather among peers of comparable status (Daloz, 2009, p. 69). Likewise, conflicts surrounding different styles of consumption - from shopping precincts to architectural styles - reflect tension between different cohorts within the elite (e.g. old money versus new money; White versus Asian; younger versus older generations). The fragmented, at times conflicting, efforts of individuals and cohorts to enhance their position within the elite, nevertheless produces a collective elite suburb cultural capital that is dynamic and perpetually moves further away from the reach of less affluent citizens. At the same time, shared cultural practices - such as those of everyday conservatism - facilitate a shared identity that bridges across differences within the elite. Everyday conservatism in elite suburbs could therefore be read as a habitus that contributes to the process of 'elite integration', allowing increasingly diversified elites to work effectively together in pursuit of collective interests (Higley, 1979, p. 265; Pietsch, 2004, p. 26).

In certain circumstances and to certain audiences, an elite neighbourhood's prestige can be used as 'ammunition' through which residents project their individual status and accrue benefits. However, the utility of prestige associated with elite suburb residency varies in different circumstances (or 'fields'). It could generate advantages in some fields (e.g. reputation of reliability in dealings with business executives), and disadvantages in others (e.g. 'Toorak prices' charged by service providers). Furthermore, the capacity to appropriate the prestige of an elite suburb is not equally shared between all residents of the elite suburb. Women and youth, for example, are more likely than adult men to be perceived as having 'inherited' rather than 'acquired' the cultural capital of an elite neighbourhood. As such, rather than an advantage, being identified as resident of an elite suburb may be a burden of stigma for women and youth in certain circumstances.

In concluding the paper, I wish to highlight three lessons for the application of Bourdieu's thinking in geographical studies of elites and the super-rich, and in social and cultural geography more broadly. Davis and Monk (2011, p. xv) vividly portray the landscapes of a contemporary "savage, fanatical capitalism", characterised by extreme spatial segregation and fortification of wealth in man-made utopias across the globe. From city-sized supermalls, through to artificial island suburbs these "alternative universes" of the superrich embody their desire for "infinite consumption, total social exclusion and physical security, and architectural monumentality - that are clearly incompatible with the ecological and moral survival of humanity". Bourdieu's theory provides alternative lens through which these spaces can be understood not only in terms of unsustainable and unethical 
consumption, but also as spaces where capital is accumulated in its varied social and cultural guises.

However, geographers and others have raised significant concerns about questions of agency, social difference and spatiality in Bourdieu's theory. Addressing these concerns, I propose that a geographical application of Bourdieu requires attention to the spatiality of the cultural capital circuit in at least three separate phases: the spatial fixing of cultural capital; the practices through which spatially fixed cultural capital is appropriated by individuals and groups; and the operationalisation or conversion of cultural capital in different fields. In concluding the paper, I wish to make a final comment about each of these three phases, as following.

Firstly, cultural capital can be understood as being spatially fixed when practices of distinction become associated with a space or spatial practice, such a body, object, place or movement (Prazeres, 2017). Yet, rather than an isolated practice of distinction that is fully contained within a place, neighbourhood cultural capital is better understood in terms of spatial intensity (Savage, 2011), as the focal point where different cultural practices (each of which extends well beyond that point) become entangled. Such sets of entangled practices have no inherent value as cultural capital, but at particular moments, through particular practices, by particular people, in particular fields, can become charged with distinction.

Secondly, as a 'neighbourhood effect' (Galster, 2012), cultural capital does not equally affect all inhabitants. In geographies of the elites and the super-rich, for example, there is growing attention to the question of whether super-rich immigrants from China are able to appropriate the cultural capital embedded in primarily White elite neighbourhoods of Western Cities (Knowles and Burrows, 2017; Author, 2017). Similar attention is required in respect to question of gender, age, and other social differences within elites.

Thirdly, the value of cultural capital is not inherent to the neighbourhood in which it is fixed, rather determined by the 'fields' in which it is operationalised, or converted into economic or other forms of capital. It is often at such moments of conversion where cultural practices, which otherwise can be habitual or driven by affective rather than purely instrumental motivations (Bridge, 2001; 2006), become explicitly charged with meanings of status and distinction. For example, the participants in my study were highly conscious and strategic about the fields in which they invoke their elite suburb residency, and those in which they disguise this fact. Yet, the spatiality of Bourdieu's 'field' has not yet been fully developed (Savage, 2011). Just how 'fields' are spatialised, and how elite cultural capital is converted into advantages or disadvantages in different fields, is therefore a useful direction for research in the geographies of elites and the super-rich. Such analysis could potentially point to new sites and forms of intervention, where redistribution is pursued not only through disruptions to the accumulation of capital by elites, but also its conversion into other forms of capital in different sites and fields. 


\section{References}

Australian Bureau of Statistics (ABS) (2016). 6523.0 Household Income and Wealth, Australia, 2013-14. http://www.abs.gov.au/ausstats/abs@.nsf/mf/6523.0

Arthurson, K. (2013). Mixed tenure communities and the effects on neighbourhood reputation and stigma: Residents' experiences from within. Cities, 35, 432-438.

Atkinson, R. (2008). The flowing enclave and the misanthropy of networked affluence. In:

Talja Blokland \& Mike Savage (eds) Networked urbanism: social capital in the city.

Hampshire: Ashgate, pp. 41-58.

Atkinson, R., Borrows, R., Glucksberg, L., Ho, H.K., Knowles, C., and Rhodes, D. (2017). Minimum city? The deeper impacts of the 'super-rich' on urban life. In: Forrest, R., Koh, S.Y., and Wissink, B. (eds) Cities and the super-rich: Real estate, elite practices and urban political economies. New York: Palgrave, pp. 253-272.

Beaverstock, J.V., Hubbard, P. and Short, J.R., (2004). Getting away with it? Exposing the geographies of the super-rich. Geoforum, 35(4), 401-407.

Bourdieu, P. (1984). Distinction: A social critique of the judgement of taste. Cambridge: Harvard University Press.

Bourdieu, P. (1986). The forms of capital. In: Richardson J G (ed) Handbook of Theory and Research for the Sociology of Education. New York: Greenwood Press, pp. 241258.

Bourdieu, P., \& Wacquant, L. (1999). On the cunning of imperialist reason. Theory, Culture \& Society, 16(1), 41-58.

Bridge, G. (2001). Bourdieu, rational action and the time-space strategy of gentrification. Transactions of the Institute of British Geographers, 26(2), 205-216.

Bridge, G. (2006). Perspectives on cultural capital and the neighbourhood. Urban Studies, 43(4), 719-730. 
Bunker, R., Holloway, D., \& Randolph, B. (2005). The expansion of urban consolidation in Sydney: Social impacts and implications. Australian Planner, 42(3), 16-25.

Daloz, J. (2009). The sociology of elite distinction: From theoretical to comparative perspectives. Basingstoke: Springer.

DeVerteuil, G. (2013). Where has NIMBY gone in urban social geography?. Social \& Cultural Geography, 14(6), 599-603.

Forrest, R., Koh, S., and Wissink, B. (2017). Hyper-divided cities and the 'immoral' super-rich: Five parting questions. In: Forrest, R., Koh, S.Y., and Wissink, B. (eds) Cities and the superrich: Real estate, elite practices and urban political economies. New York: Palgrave, pp. 273288.

Gladstone, N. (2018). Sydney's biggest NIMBY and developer friendly councils, Accessed 16 February 2018: http://www.smh.com.au/nsw/sydneys-biggest-nimby-and-developerfriendly-councils-20180111-h0h6z2.html

Hanquinet, L., Savage, M., \& Callier, L. (2012). Elaborating Bourdieu's field analysis in urban studies: cultural dynamics in Brussels. Urban Geography, 33(4), 508-529.

Hay, I. (2013). Geographies of the Super-rich. Edward Elgar Publishing.

Higley, J., Deacon, D., \& Smart, D. (1979). Elites in Australia. London: Routledge.

Holmqvist, M. (2017). Leader communities: The consecration of elites in Djursholm, New York: Columbia University Press.

Honderich, T. (2005). Conservatism: Burke, Nozick, Bush, Blair?, London: Pluto.

Jager, M. (1986). Class definition and the esthetics of gentrification: Victoriana in Melbourne. In Gentrification of the City (pp. 94-107). Routledge.

Kelaher, M., Warr, D. J., Feldman, P., \& Tacticos, T. (2010). Living in 'Birdsville': Exploring the impact of neighbourhood stigma on health. Health \& place, 16(2), 381-388.

Knowles, C., \& Burrows, R. (2017). Reimagining Chinese London. In: Burdett, R. and Hall, S. (eds.) The SAGE Handbook of the 21st Century City, pp. 87-103.

McKnight, D. (2005). Beyond Right and Left: New politics and the culture wars. Sydney: Allen \& Unwin.

Accepted version of: Wiesel, I. (2018). Producing and appropriating neighbourhood prestige: cultural capital in Australia's elite suburbs. Social \& Cultural Geography, 1-26. https://www.tandfonline.com/doi/abs/10.1080/14649365.2018.1541249 
O’Hara, K. (2012). Conservatism. London: Reaktion Books.

Ollivier, M. (2008). Revisiting Distinction: Bourdieu without class? Journal of Cultural Economy, 1(3), 263-279.

Painter, J. (2000). Pierre Bourdieu. In: Crang M and Thrift N (eds) Thinking Space, London: Routledge, pp. 239-59.

Paris, C. (2016). 12. The residential spaces of the super-rich. In: Hay, I. and Beaverstock, J. (eds) Handbook on Wealth and the Super-Rich. Cheltenham, Edward Elgar, pp. 244-263.

Pietsch, Samuel (2004). To have and to hold on to: wealth, power and the capitalist class. In: Rick Kuhn (ed) Class and struggle in Australia. Sydney: Perason Longman, pp. 39-54.

Pow, Choon-Piew (2011). Living it up: Super-rich enclave and transnational elite urbanism in Singapore. Geoforum, 42(3) 382-393.

Real Estate Australia (2016a). Melbourne's most expensive suburbs revealed (http://www.realestate.com.au/news/most-expensive-suburbs-in-melbourne/) (accessed 8 May 2017).

Real Estate Australia (2016b). Western Australia's most expensive suburbs revealed (https://www.therealestateconversation.com.au/2016/07/06/western-australias-mostexpensive-suburbs/1467799099) (accessed 8 May 2017).

Real Estate Australia (2016c). http://www.realestate.com.au/news/most-expensivesuburbs-in-australia-2016/ (http://www.realestate.com.au/news/most-expensive-suburbsin-australia-2016/) (accessed 8 May 2017).

Richardson, C., \& Skott-Myhre, H. A. (Eds.). (2012). Habitus of the Hood. Bristol: Intellect Books.

Rose-Redwood, R. S. (2008). From number to name: symbolic capital, places of memory and the politics of street renaming in New York City. Social \& Cultural Geography, 9(4), 431-452.

Souter, G.G. (1993). Mosman: a History, Melbourne: Melbourne University Press. 
Savage, M. (2011). The lost urban sociology of Pierre Bourdieu. The new Blackwell companion to the city, 511-520.

Savage, M., Bagnall, G., \& Longhurst, B. J. (2004). Globalization and belonging. London: Sage.

Short, J.R. (2013). Economic wealth and political power in the second Gilded Age. Geographies of the Super-Rich. Cheltenham: Edward Elgar Publishing, pp.26-42.

Veblen, T. (1899). Theory of the Leisure Class: An Economic Study of Institutions. Project Gutenberg. http://www.gutenberg.org/files/833/833-h/833-h.htm

Walby, S., Armstrong, J., \& Strid, S. (2012). Intersectionality: Multiple inequalities in social theory. Sociology, 46(2), 224-240.

Wiesel, I., Liu, F., \& Buckle, C. (2017) Locational disadvantage and the spatial distribution of government expenditure on urban infrastructure and services in metropolitan Sydney (1988-2015). Geographical Research. Online First, DOI 10.1111/1745-5871.12245 